\title{
FORMING OF SOFT COMPETENCIES EDUCATIONAL PROCESS MANAGEMENT CHANGES (DISTANCE EDUCATION)
}

\author{
Ji Fenlai \\ H.S. Skovoroda Kharkiv National Pedagogical University, Ukraine \\ Nadiia Kalashnyk \\ Lviv Regional Institute for Public Administration of the National Academy for Public \\ Administration under the President of Ukraine, Ukraine \\ Raisa Chernovol-Tkachenko \\ H.S. Skovoroda Kharkiv National Pedagogical University, Ukraine \\ Li Sinje \\ H.S. Skovoroda Kharkiv National Pedagogical University, Ukraine
}

\section{Liu Zhijian}

H.S. Skovoroda Kharkiv National Pedagogical University, Ukraine

\begin{abstract}
The impetus and innovative idea for research was the rapid transformational changes in society. These changes were expressed in the experimental search activities of the development in education and other social and humanitarian sciences, which are now taking place in the world in connection with the COVID-19 pandemic and the maximum distanceization of processes, including educational ones. The authors concluded that these changes concern: teaching methods, organization and management of educational processes. In practical teaching, the authors noticed the peculiarities of soft competencies formation in distance learning. Unlike knowledge, soft competencies are formed in social interaction. It is completely different in content and forms of construction in online education than in the offline one. These changes in educational transformations and management of educational processes take place due to fundamental transformations under the influence of: scientific and technological progress, global security challenges, wide access to information, significant part of life virtualization, restructuring of the axis of the teaching paradigm, etc.

The main idea of the article is focused on changes of soft competencies formation as they are understood in distance learning; also it was emphasized the changes, necessary for successful teachers' work management in this area. Research methods: general scientific (analysis, synthesis, collection of information, expert opinions, forecasting and modeling), special scientific (analysis of changes in law, recommended practices, observation, authors' own practice and fixation in changes in the educational results of their students).
\end{abstract}

Keywords: applied and empirical aesthetics, competence, digital aesthetics, educational policy, management of educational processes, mixed forms of education, sustainable education. 
Ji Fenlai et al., 2021 Forming of Soft Competencies Educational Process Management Changes (Distance Education)

\section{Introduction}

Mastering distance teaching imposed by the COVID-19 pandemic was challenging for many teachers. According to the UN worldwide, in the period 2020-2021, more than 1.5 billion students at various levels faced the closure of educational institutions (schools, colleges, universities etc.) due to the COVID-19 pandemic (UNESCO, 2020). And here we are talking about educational institutions of different levels. If we take the field of professional education, the number of people can be twice as high. Society was forced to respond quickly to changes, including the education system. Changes in the educational policy of all countries went in two directions: the first - changes in technology (from offline to online), the second - changes in the processes and teaching tools. After the series of lockdowns, countries are gradually returning to pre-quarantine forms of education. For this, mixed forms of learning are used (alternation of online and offline learning). We expect that such forms of education will take hold in education systems at least until the end of the 2021-2022 academic year. But this is two years of the educational process. These years should be effective for students of all educational levels. They cannot be returned.

The educational process should be continuous, students should receive educational services despite the pandemic - this was the first reaction of educational systems around the world. But for the quality of education, both: subject (hard) competence and soft competence are equally important. In the context of distance education, it turned out to be easier to form hard competencies (reliance on knowledge) than soft competencies (reliance on communication systems). The research aim of the article is: to consider the discussion issues of the soft competence formation in nowadays conditions and offer our own solutions to problems. In the study of the problem, the authors used general scientific methods (analysis, synthesis, information collection, etc.) and special scientific methods (recommended practices, observation, authors' own practice, etc.).

\section{Literature Review}

Scientific researches analysis in the field of soft competencies educational process management changes by distance or mixed forms' education instruments nowadays predominantly associates with COVID-19 crises. The surge of research comes in April-June 2020. The main feature of researches is the focus on distance learning instruments during COVID-19 educational crises, for example M. Goetz draws attention to the difficulties in the work of teachers during the transition to distance learning (Goetz, 2020); S. G. Huber and C. Helm describes such digital tool "School Barometer", what was used in Germany, Austria and Switzerland 
(Huber \& Helm, 2020); A. Bakker and D. Wagner research the problems of COVID-19 pandemic consequences for education at the example of mathematics teaching (Bakker \& Wagner, 2020). The group of researches: J. Crawford, K. Butler-Henderson, J. Rudolph, B. Malkawi, M. Glowatz, R. Burton, P.A. Magni and S. Lam studies international experience and experience of different countries in the field of distance learning (Crawford et al., 2020). Problems of online teaching in higher education have been studied in scientific and practical researches: "COVID -19 and online teaching in higher education: A case study of Peking University" (Bao, 2020), "Using technology to maintain the education of residents during the COVID-19 pandemic" (Chick et al., 2020). All described are certain practices in distance learning, but especially interesting for our article were studies on changing the principles and processes in educational management during the COVID-19 pandemic (Luo, Liu, Yue, \& Rosen, 2020) etc. Unfortunately, the problem of the soft competencies formation and changes in education management in connection with distance and mixed forms of education are studied a very little or not at all in these researches. So, the main literature for this paper in the focus of forming of soft competencies educational process management changes are: recommendations and practices of distance learning on COVID-19 in the world and some countries, which can be seen as basis for the analysis; official statements (speeches) of government leaders, senior officials of international organizations, international experience and experience of different countries, own practice of authors etc.

\section{Methodology}

The methodology for studying the problems of forming of soft competencies educational process management changes by distance or mixed forms' education instruments in the context of the COVID-19 pandemic and the quarantine withdrawal period was identified as follows: methods of theoretical analysis (studying the content of pedagogical instruments and decision theory under conditions of unpredictable results), analogies (based on the patterns of human development, population groups and society), studying regulatory acts of international organizations from open official sources of information, expert opinions, forecasting and modeling, recommended practices, observation, authors' own practice. 
Ji Fenlai et al., 2021 Forming of Soft Competencies Educational Process Management Changes (Distance Education)

\section{Research Results}

The educational crisis of 2020 has become a challenge both for those who teach and for those who study, regardless of the level of education. The first reaction from governments around the world was to create online information platforms for learning under quarantine conditions. The UNESCO Assistant Director-General for Education characterized the Geneva EiE Hub as the platform that the modern world needs. This platform should combine political and institutional influence to aims increased funding for education and resources equitable distribution. The Geneva EiE Hub is committed to acting effectively as a catalyst for long-term financial and political commitment, recognition of the most vulnerable learners, and innovative solutions to foster educational inclusion.

Nowadays, UNESCO strongly supports this initiative as an important step towards the implementation of the Education 2030 Framework for Action. This Program indicates the necessary to develop national education systems that will be more flexible and resilient in the face of natural hazards, military and other conflicts, mass and social unrest. This is very important to ensure the continuity of education in emergency, crisis, conflict, pandemic and post-crisis situations. UNESCO will work towards supporting lifelong learning in times of crisis. For this, the Organization is ready to apply all its tactical experience in planning, statistics and policy in education area.

In the context of the global crisis, UNESCO recommended such educational activities in a pandemic. First of all the most suitable and common educational tools should be selected. Programs of distance learning must be inclusive. In the conditions of distance and mixed forms of education, it is necessary to ensure all participants in the educational process confidentiality (privacy) and security data. There should be clear planning of distance and mixed form learning programs activities (short-term long-term planning). The solutions to the psychosocial problems of all educational process participants should precede the learning process and the teaching process. Technical support should be provided to teachers and parents on the use of digital education tools in distance learning. The number of educational applications and platforms used should be limited; also as it should to combine appropriate approaches. It is necessary to monitor the progress of students; for this, it is important to develop clear and understandable rules for distance learning and control. The distance learning units' length should be determined based on the self-regulation skill levels of learners. Technically and organizationally communication with all educational process participants must be provided. Communities should be formed (UNESCO and partners..., 2021).

In our opinion, the main problem is: the implementation of these recommendations helps to ensure, first of all: school (compulsory education), the continuity of educational processes in educational institutions, and organize the 
lessons technically (digital processes). But the content of the competencies formation remains in the area of teachers' responsibility. As we mentioned early, in the context of distance education, the main focus comes to form hard competencies (reliance on knowledge) than soft competencies (reliance on communication systems). We see two groups of prerequisites for this: communication with the help of information technologies is different in its structure than "live communication" (the mood of the collective is not felt, the hierarchy is erased, there is no need for time frames "here and now" or they are softer, a different degree of responsibility, etc.) and different levels of technical readiness for distance learning (depending on the country, region, financial situation, previous online experience, etc.). This is equally true for teachers and students.

The first negative trends were noticed by the teachers in the autumn of 2020, when the students came back to educational institutions after a long break. Many students (especially teenagers) found it difficult to establish communication with peers and teachers (Ministry of Education..., 2020). The online form of education turned out to be more comfortable for them, but less effective in terms of readiness for life. Then the question became acute that half a year online had an irrational effect on the formation of soft competencies among students. This is not only about the fact that the students did not form and develop new soft competencies, but also lost the skills that were already formed by March 2020.

We make it clear, that with different approaches in Pedagogy to understanding the category of "soft competence", we share the point of view that these include: leadership skills; decision making skills; communication skills; thinking and problem solving skills; teamwork skills) interpersonal skills and entrepreneurship skills (Mohamad, Yee, Tee, Mukhtar, \& Ahmad, 2017). In the context of success in life and work, there are skills that individuals need meet the organizational and personal goals to achieve all the factors of quality personality and worker. And the educational crisis of 2020 was primarily reflected in the formation of these competencies. If, under the conditions of quarantine, online learning remains the leading form of education, society risks getting a generation of people with poorly formed social skills.

Special attention should be paid to teaching of aesthetically oriented disciplines` peculiarities in mixed forms of education or distance education. This problematic is formed according to the contradiction of modern mainstreams: the actualization of the aestheticization of life (as a new paradigm for the development of society as an emotionally-rational form of reality mastering) and the massive going online over the past year (the general tendency to be saved after the Pandemic). It explains the increased interest as to implementation of aesthetic norms in the professional activity and daily life of every person. The trend is increasing in the educational process when it comes to professional activities and 
training of specialists, for whom the aesthetic component is professionally determining (artists, choreographers, designers, musicians etc.). Today, the question of the applied and empirical aesthetics, the aesthetics of the digital space, acquires a new rethinking.

The authors have carried out the results of a study of professional competence aesthetic content through such aspects: self-presentation, demand for professional activity and specialist, perception of the results of professional activity, enjoyment of professional activity, individual style of activity formation, etc. Authors analyze the problem in the context of working with aesthetically oriented disciplines in online and offline forms, as well as in mixed forms of education.

As practicing teachers, we can state that distance learning reduces the effectiveness of the aesthetic and practical skills formation in the training of choreographers, vocalists, musicians, actors, etc. The distortion and limitation of spatial, visual and auditory perception, which are inevitable in online classes (technical resources), reduces the effectiveness of learning.

\section{Conclusions and Discussion}

Nowadays, digital skills are critical important for social inclusion, social success and jobs in modern world. To realize the digitalization opportunities, governments and communities need to understand trends in social processes, including jobs and the successful worker skill. We agree that in many ways digitalization has helped humanity survive the COVID-19 crisis. We also realize that there will no longer be a return to the forms and types of education of the prequarantine period. On the other hand, the educational crisis of 2020 demonstrates a number of problems that we must solve now, otherwise a huge number of children around the world will not be ready to realize themselves in life.

In the context of forming of soft competencies educational process management changes by distance or mixed forms of education the main problems are:

- changing the content of communication (online communication suggests one-to-one communication, in any case, students perceive it this way);

- $\quad$ different levels of technical readiness for distance learning (depending on the country, region, financial situation, previous online experience, etc.);

- $\quad$ changes in the perception of events when you are not a participant in them (events, problems that need to be solved, on-line seem distant and unreal); 
- changes in social relations "teacher-student", "student-student", "student-other students" (connections with those with whom students communicate comfortably and weakened connections with whom students communicate uncomfortably, general communication skills decrease);

- $\quad$ some professionally important skills cannot be fully formed online (for example, aesthetically oriented professions).

Next few years, we see the following possible ways out of the crisis:

- $\quad$ increase in the number and time of offline training;

- emphasis in the educational process on common group activities for the socially important competencies formation;

- measures to form approximately the same technical capabilities for all participants in the educational process;

- $\quad$ additional opportunities for the formation of soft competencies among students in those professions, where social and aesthetic component are critically important.

\section{References}

Bakker, A., \& Wagner, D. (2020). Pandemic: lessons for today and tomorrow? Educational Studies in Mathematics, 104(1), 1-4. DOI: https://doi.org/10.1007/s10649-020-09946-3

Bao, W. (2020). COVID -19 and online teaching in higher education: A case study of Peking University. Human Behavior and Emerging Technologies, 2(2), 113-115. DOI: https://doi.org/10.1002/hbe2.191

Chick, R. C., Clifton, G. T., Peace, K. M., Propper, B. W., Hale, D. F., Alseidi, A. A., \& Vreeland, T. J. (2020). Using technology to maintain the education of residents during the COVID-19 pandemic. Journal of Surgical Education 77(4), 729-732. DOI: https://doi.org/10.1016/j.jsurg.2020.03.018

Crawford, J., Butler-Henderson, K., Rudolph, J., Malkawi, B., Glowatz, M., Burton, R., Magni, P. A., \& Lam, S. (2020). COVID-19: 20 countries' higher education intra-period digital pedagogy responses. Journal of Applied Learning \& Teaching, 3(1), 9-28. DOI: https://doi.org/10.37074/jalt.2020.3.1.7

Goetz, M. (2020). Distance Learning in der Covid-19 Krise: Ein Praxischeck. Medienimpulse, 58, 1-21. DOI: https://doi.org/10.21243/mi-02-20-19

Huber, S. G., \& Helm, C. (2020). COVID-19 and schooling: evaluation, assessment and accountability in times of crises - reacting quickly to explore key issues for policy, practice and research with the school barometer. Educational Assessment, Evaluation and Accountability, 32, 237-270. DOI: https://doi.org/10.1007/s11092-020-09322-y

Luo, Y. M., Liu, W., Yue, X. G., \& Rosen, M. A. (2020). Sustainable emergency management based on intelligent information processing. Sustainability (Switzerland), 12(3), 10 13. DOI: https://doi.org/10.3390/su12031081

Ministry of Education and Science of Ukraine. (2020). Letter . On the organization of distance learning. Lyst Ministerstva osvity ta nauky Ukrayiny vid 02.11.2020 "Shchodo 
Ji Fenlai et al., 2021 Forming of Soft Competencies Educational Process Management Changes (Distance Education)

orhanizatsiyi dystantsiynoho navchannya" [Datafile]. Retrieved from: https://mon.gov. ua/ua/npa/shodo-organizaciyi-distancijnogo-navchannya

Mohamad, M., Yee, M., Tee, T., Ibrahim Mukhtar, \& Ahmad, A. (2017). Soft skills in pedagogical practices with different curriculum for engineering education. International Research and Innovation Summit (IRIS2017). DOI: doi:10.1088/1757-899X/226/ $1 / 012191$

UNESCO. (2021). Education: From disruption to recovery. Accessed 12 December 2020. [Report] Retrieved from: https://en.unesco.org/covid19/educationresponse/

UNESCO. (2021). UNESCO and partners launch of the Geneva Global Education in Emergencies Hub. [Report] Retrieved from: https://en.unesco.org/news/unesco-andpartners-launch-geneva-global-education-emergencies-hub 